\title{
MODELING THE RADIOCARBON RESERVOIR EFFECT IN LACUSTRINE SYSTEMS
}

\author{
Shi-Yong $\mathrm{Yu}^{1,2} \bullet \mathrm{Ji}$ Shen $^{3} \bullet$ Steven M Colman ${ }^{1,4}$ \\ ABSTRACT. The modern water (both pre- and post-atmospheric nuclear testing) of most lakes has an anomalously old \\ apparent radiocarbon age due to what is commonly referred to as the "reservoir effect." In contrast to marine settings, this ${ }^{14} \mathrm{C}$ - \\ offset phenomenon is primarily caused by pre-aged carbon discharged to lakes by rivers and/or groundwater. In this paper, a \\ 2-component box model based on the principle of ${ }^{14} \mathrm{C}$ mass balance in lake water and in the early diagenesis zone was for- \\ mulated to address the relative importance of terrestrial inputs, autochthonous production, and biogeochemical processes in \\ the ${ }^{14} \mathrm{C}$ reservoir of a lacustrine system. The model was tested using observed data from Lake Qinghai, the largest inland water \\ body in China. Our inverse modeling using Markov chain Monte Carlo (MCMC) techniques yields best estimates of the $\delta^{14} \mathrm{C}$ \\ of DIC in river ( $\sim 118 \%$ modern) and groundwater ( $76 \%$ modern), as well as the $\delta^{14} \mathrm{C}$ of DOC in river water ( $70 \%$ modern) \\ during the post-bomb era. Assuming that these parameters remain constant over time, our modeling indicates that both the \\ DIC and DOC pool of this lake have reservoir ages of about $1500 \mathrm{yr}$ for the pre-bomb era, generally consistent with estimates \\ obtained by extrapolation of the age-depth models of 2 sediment cores to the sediment surface.
}

\section{INTRODUCTION}

Lake sediments are exceptional archives of environmental and climate changes at various spatial and temporal scales. The temporal framework of lacustrine records on timescales of hundreds to thousands of years is commonly constrained using radiocarbon dating of ${ }^{14} \mathrm{C}$-bearing materials. In many lakes, desirable materials such as terrigenous macrofossils are scarce in sediment cores (Fowler et al. 1986), so that only bulk organic material (OM) or carbonate is available. A good chronology is critical not only to evaluating the rate and cyclicity of environmental changes, but also to understanding the leads and lags of climate events and, ultimately, their forcing mechanisms. However, the reliability of dating lacustrine bulk carbonate or OM samples is subject to large temporal and spatial uncertainties of the ${ }^{14} \mathrm{C}$ reservoir effect (Godwin 1951; Deevey et al. 1954; Broecker and Walton 1959; MacDonald et al. 1991), particularly for samples from hardwater lakes within carbonate watersheds. Anomalous ${ }^{14} \mathrm{C}$ contents may result from dissolution of ancient carbonates (the "hardwater effect") and/or organic matter that resides on the landscape before being introduced to the lake. A typical example is Lake Qinghai, China's largest inland water body situated on the northeastern margin of the Tibetan Plateau.

The epilimnia of most lakes are well mixed and tend to be saturated with respect to atmospheric $\mathrm{CO}_{2}$ (Cole et al. 1994), and thus the ${ }^{14} \mathrm{C}$ equilibrates between the lake and the atmosphere (Broecker and Walton 1959). Accordingly, anomalous ${ }^{14} \mathrm{C}$ contents in most lakes - to a large extent-are caused by the introduction of pre-aged carbon, that is, carbon that is radiogenically older than the true age of the lake water or surface sediment, thereby giving an apparent age to the carbon pool of the lake. Such pre-aged carbon can include dissolved organic carbon (DOC), particulate organic carbon (POC), and dissolved inorganic carbon (DIC) from river and/or groundwater discharges (Nelson et al. 1988; Benson 1993; Abbott and Stafford 1996; Xu and Zheng 2003). Changes in ${ }^{14} \mathrm{C}$ content due to pre-aged DIC are often called the "hardwater effect." Carbon may "age" further due to radioactive decay while recycling in the lake water column, or to early diagenesis after being deposited at the sediment-water interface ("residence age"). Finally, carbon, especially POC, may spend some time

\footnotetext{
${ }^{1}$ Large Lakes Observatory, University of Minnesota Duluth, 2205 East 5th Street, Duluth, Minnesota 55812, USA.

${ }^{2}$ Corresponding author. Email: syu@d.umn.edu.

${ }^{3}$ Nanjing Institute of Geography and Limnology, Chinese Academy of Sciences, Nanjing 210008, People's Republic of China.

${ }^{4}$ Department of Geological Sciences, University of Minnesota Duluth, Duluth, Minnesota 55812, USA.
} 
before actually being deposited in the lake and acquire an "inherited age." Therefore, a "modern" lacustrine system can have an apparent ${ }^{14} \mathrm{C}$ age acquired by a variety of processes, the effects of which we collectively call the "reservoir age" of the lake.

Several methods have been developed for determining the reservoir age in lacustrine settings (e.g. MacDonald et al. 1991; Rea and Colman 1995; Colman et al. 2000); these include dating paired wood/shell samples or dating the pre-bomb known-age aquatic organisms from museum collections. An alternative approach is the parallel dating of lacustrine authigenic carbonate using $\mathrm{U} / \mathrm{Th}$ and ${ }^{14} \mathrm{C}$ methods (e.g. Hall and Henderson 2001). ${ }^{14} \mathrm{C}$ analyses of DOC or DIC in lake water are becoming more common (e.g. Doran et al. 1999; Geyh et al. 1999; Stiller et al. 2001; Moreton et al. 2004; Hendy and Hall 2006). However, ${ }^{14} \mathrm{C}$ dating of recent samples has become complicated by disturbance of the atmospheric ${ }^{14} \mathrm{C}$ pool by the combustion of fossil fuels (the Suess effect) and, since 1950 (the "post-bomb era"), the atmospheric testing of nuclear devices (Broecker and Olson 1960; Pearson et al. 1986; Stuiver and Braziunas 1993). The former depletes the ${ }^{14} \mathrm{C}$ content of the atmosphere, the latter enriches it. At this point, accurate estimates of pre-bomb reservoir ages are difficult.

Driven by a number of physical and biogeochemical processes, the carbon pool of lake water is very dynamic and complicated. The budget of ${ }^{14} \mathrm{C}$ in the lake water column is essentially controlled by the gas exchange rates with the atmosphere, hydrological exchange rates with the catchment, and radioactive decay while cycling in the water column. In addition, after sinking from the water column and reaching the sediment-water interface, the ${ }^{14} \mathrm{C}$ may be further depleted due to early diagenesis, and re-introduced to the lake carbon pool. This effect on the reservoir age has not always been considered in previous studies (Broecker and Walton 1959; Deevey and Stuiver 1964; Peng and Broecker 1980; Geyh et al. 1998). Here, we first considered the various biogeochemical processes in a fully coupled 2-component box model, based on the principle of ${ }^{14} \mathrm{C}$ mass balance in the lake water column and in the early diagenesis zone. We then applied this generic model to Lake Qinghai to predict the pre-bomb reservoir ages of both organic and inorganic carbon. The model parameters for the Lake Qinghai case were estimated using the Markov chain Monte Carlo (MCMC) method. This inverse modeling approach yields estimates of the pre-bomb reservoir age of DIC and DOC that fit very well with observations.

\section{BOX MODEL FOR THE MASS BALANCE OF LACUSTRINE RADIOCARBON}

A fully coupled 2-component box model based on the principle of isotope mass balance was used to estimate the ${ }^{14} \mathrm{C}$ budget of organic and inorganic carbon in a lake system (Figure 1): One box represents the lake water column, and the other the early diagenesis zone in the sediments. Each box is treated as a well-mixed reservoir in steady state. At the water/air interface and within the boxes, small-scale transient hydrological and atmospheric processes are not considered.

\section{Box of the Water Column}

This box represents a mixture of dissolved carbon (DOC and DIC) from various pre-aged sources. Particulate carbon derived from the catchment, e.g. plant macrofossils and detrital carbonate, is not included in this model because it is usually scarce; ${ }^{14} \mathrm{C}$ dating of detrital materials is beyond the scope of this paper. In this box, the mass balance of the DOC or DIC pool at steady state can be expressed as:

$$
\frac{d M_{W}}{d t}=\left(V_{R I} F_{R}+V_{G I} F_{G}+A_{I}\right)-\left(V_{R O} F_{W}+V_{G O} F_{W}+P+A_{O}\right)=0
$$




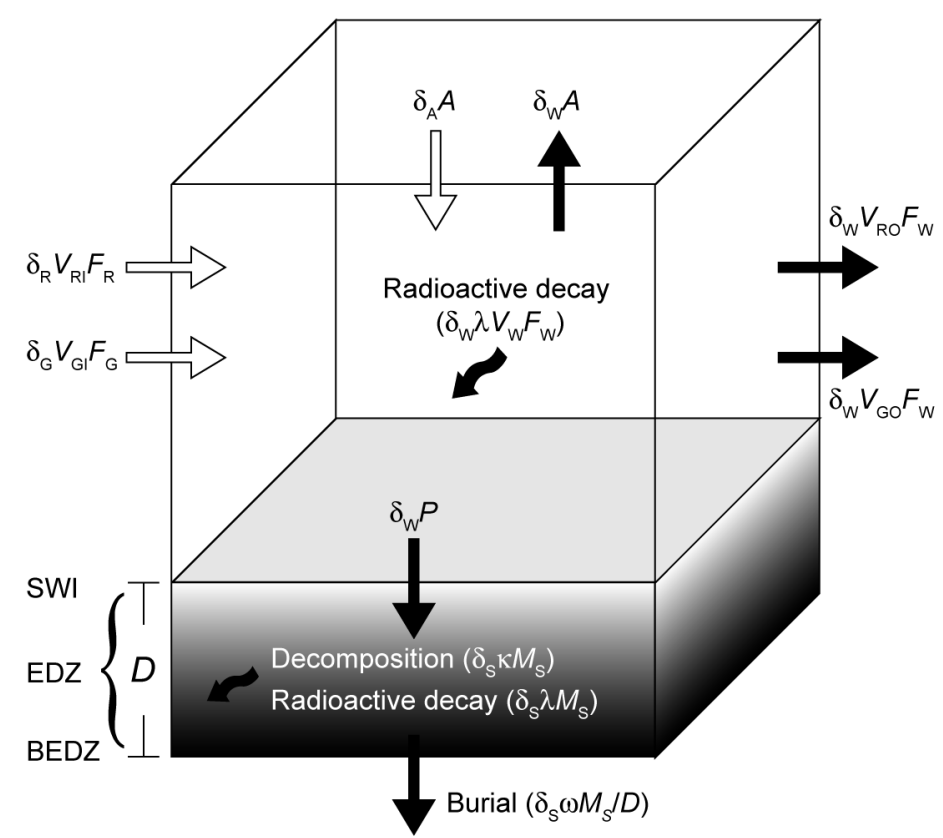

Figure 1 Two-component box model illustrating the mass budget of ${ }^{14} \mathrm{C}$ in a lacustrine sediment system. SWI: sediment-water interface; EDZ: early diagenesis zone; BEDZ: base of early diagenesis zone; $D$ : thickness of early diagenesis zone.

where $M_{W}$ is the amount in moles of carbon in lake water; $V_{R I}, V_{G I}, V_{R O}$, and $V_{G O}$ represent annual river runoff, groundwater discharge, river outflow, and groundwater leakage, respectively; $F_{R}, F_{G}$, and $F_{W}$ are the concentrations in moles per liter of DOC or DIC in river, groundwater, and lake water, respectively; $A$ is the annual flux of $\mathrm{CO}_{2}$ between lake water and the atmosphere; and $P$ is the physical or chemical flux of dissolved carbon onto the sediment-water interface each year. The $\mathrm{CO}_{2}$ exchange between lake water and the atmosphere is assumed to equilibrate. Therefore:

$$
A_{I}=A_{O}=A
$$

Solving Equation 1 for $P$, we obtain:

$$
P=V_{R I} F_{R}+V_{G I} F_{G}-V_{R O} F_{W}-V_{G O} F_{W}
$$

The total amount of incoming ${ }^{14} \mathrm{C}$ from river runoff $\left(\delta_{R} V_{R I} F_{R}\right)$, groundwater $\left(\delta_{G} V_{G I} F_{G}\right)$, and the atmosphere $\left(\delta_{A} A\right)$ is balanced by river outflow $\left(\delta_{W} V_{R O} F_{W}\right)$, groundwater leakage $\left(\delta_{W} V_{G O} F_{W}\right)$, deposition $\left(\delta_{W} P\right)$, "respiration" $\left(\delta_{W} A\right)$, and radioactive decay $\left(\delta_{W} \lambda V_{W} F_{W}\right)$. Therefore, the ${ }^{14} \mathrm{C}$ mass balance in the DOC or DIC pool can be written as:

$$
\frac{d \delta_{W} M_{W}}{d t}=\left(\delta_{R} V_{R I} F_{R}+\delta_{G} V_{G I} F_{G}+\delta_{A} A\right)-\left(\delta_{W} V_{R O} F_{W}+\delta_{W} V_{G O} F_{W}+\delta_{W} P+\delta_{W} A+\delta_{W} \lambda V_{W} F_{W}\right)=0
$$

where the $\delta$ notation denotes the radioactivity of dissolved carbon in different reservoirs, usually given as the ratio of radiocarbon $\left({ }^{14} \mathrm{C}\right)$ atoms to ordinary carbon $\left({ }^{12} \mathrm{C}\right)$ atoms; $V_{W}$ is lake volume; and $\lambda$ is the ${ }^{14} \mathrm{C}$ decay constant. Substituting $P$ with Equation 3, and after combining the like terms, the $\delta^{14} \mathrm{C}$ of the DOC or DIC pool can be solved as: 


$$
\delta_{W}=\frac{\delta_{R} V_{R I} F_{R}+\delta_{G} V_{G I} F_{G}+\delta_{A} A}{V_{R I} F_{R}+V_{G I} F_{G}+A+\lambda V_{W} F_{W}}
$$

\section{Box of the Early Diagenesis Zone}

DOC or DIC, after sinking through the lake water column and being deposited at the sediment/water interface in the form of OM or precipitated carbonate, may experience a number of biogeochemical processes known as early diagenesis. The buried remnants eventually pass through the base of the early diagenesis zone (Figure 1) and become available as datable materials for geological records. A theoretical description of these processes has been detailed by Berner (1980). In the box of the early diagenesis zone, incoming OM or carbonate, $P$, from the water column is balanced by aerobic decomposition or dissolution $\left(\kappa M_{S}\right)$, respectively, and burial $\left(\omega \frac{M_{S}}{D}\right)$. Therefore, the steady-state
equation for the mass budget of $\mathrm{OM}$ or carbonate is written as:

$$
\frac{d M_{S}}{d t}=P-\left(\kappa M_{S}+\omega \frac{M_{S}}{D}\right)=0
$$

where $M_{S}$ is the amount in moles of $\mathrm{OM}$ or carbonate in the early diagenesis zone, $\kappa$ is the aerobic decomposition or dissolution constant, $\omega$ is mass sedimentation rate, and $D$ is the thickness of the early diagenesis zone. Solving Equation 6 for $M_{S}$ results in:

$$
M_{S}=\frac{P}{\kappa+\omega / D}
$$

At steady state, the input $\left(\delta_{W} P\right)$ should be balanced by the output, due to aerobic decomposition or dissolution $\left(\delta_{S} \kappa M_{S}\right)$, the radioactive decay $\left(\delta_{S} \lambda M_{S}\right)$, and burial $\left(\delta_{S} \omega M_{S} / D\right)$ :

$$
\frac{d \delta_{S} M_{S}}{d t}=\delta_{W} P-\left(\delta_{S} \kappa M_{S}+\delta_{S} \lambda M_{S}+\delta_{S} \omega \frac{M_{S}}{D}\right)=0
$$

Substituting Equation 7 into 8 , and solving for $\delta_{S}$, we obtain the $\delta^{14} \mathrm{C}$ of OM or carbonate in the early diagenesis zone:

$$
\delta_{S}=\frac{\kappa+\omega / D}{\kappa+\lambda+\omega / D} \delta_{W}
$$

Then, by the exponential law of radioactive decay:

$$
\delta_{S}=\frac{\kappa+\omega / D}{\kappa+\lambda+\omega / D} \delta_{W}=\delta_{R A} e^{-\lambda T}
$$

where $\delta_{R A}$ is the $\delta^{14} \mathrm{C}$ level of the reference (AD 1950) atmosphere. Substituting Equation 5 into Equation 10, the total reservoir age of OM or carbonate in a lake system can be solved:

$$
T=\frac{1}{\lambda} \ln \left[\frac{\delta_{R A}}{\delta_{W}}\left(1+\frac{\lambda}{\kappa+\omega / D}\right)\right]=\frac{1}{\lambda} \ln \left[\frac{V_{R I} F_{R}+V_{G I} F_{G}+A+\lambda V_{W} F_{W}}{\frac{\delta_{R}}{\delta_{R A}} V_{R I} F_{R}+\frac{\delta_{G}}{\delta_{R A}} V_{G I} F_{G}+\frac{\delta_{A}}{\delta_{R A}} A}\left(1+\frac{\lambda}{\kappa+\omega / D}\right)\right]
$$

Equation 11 states that the reservoir age of a lake sediment system, as usually used for correcting the ${ }^{14} \mathrm{C}$ dates of bulk OM or carbonate samples, is a sum of the anomalous ages: 1) inherited from var- 
ious pre-aged sources such as the catchment topsoil, aquifers, and bedrock; and 2) gained from ${ }^{14} \mathrm{C}$ decay while recycling in the lake water column and in the early diagenesis zone.

\section{APPLICATION TO LAKE QINGHAI}

\section{Geographical and Hydrological Settings}

Situated on the northeastern edge of the Tibetan Plateau (Figure $2 \mathrm{~A})$, Lake Qinghai $\left(37^{\circ} \mathrm{N}, 100^{\circ} \mathrm{E}\right)$ is the largest inland water body in China by surface area $\left(\sim 4340 \mathrm{~km}^{2}\right)$. The lake is located in a relatively simple piggyback basin in a larger complex of strike-slip and thrust faulting. The lake basin, consisting of 3 sub-basins, is hydrologically closed (Figure 2B). The topography of the northern sub-basin is controlled by several minor faults, whereas the southern ones represent relatively stable sedimentary environments, with an average recent sedimentation rate estimated at $1.4 \mathrm{~mm} / \mathrm{yr}$ using the ${ }^{210} \mathrm{~Pb}$ method (Huang and Sun 1989; Zhang 2003; Henderson 2004). The lake water is brackish to saline (average salinity $14.1 \mathrm{~g} / \mathrm{L} ; \mathrm{pH} 9.2$ ). Among 5 large rivers seasonally draining the watershed, which is partly underlain by late-Paleozoic limestone, the Buha River is the largest, carrying almost $50 \%$ of the total runoff and $70 \%$ of the total fluvial sand to the lake. Based on a water balance, annual discharge of groundwater to the lake is estimated at $0.6 \times 10^{9} \mathrm{~m}^{3}$ (Kelts et al. 1989).
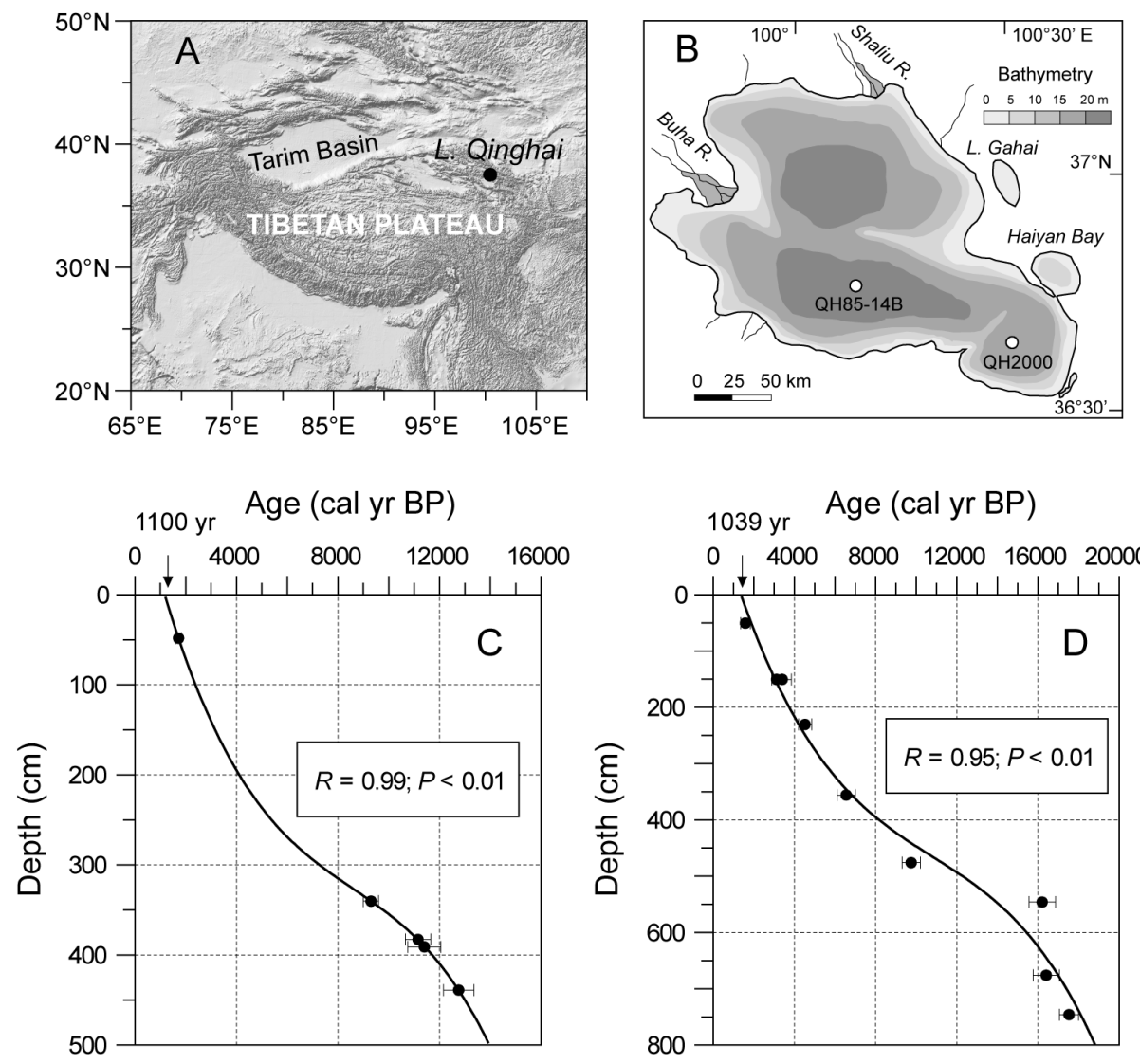

Figure 2 A) Shaded relief map of Lake Qinghai and the surrounding area; B) map showing the bathymetry of Lake Qinghai and the location of cores; C) age-depth model for Core QH85-14B (Kelts et al. 1989); D) age-depth model for Core QH2000 (Shen et al. 2005). 
Owing to its unique geographical location, the importance of Lake Qinghai for sediment records of long-term variations of the Asian monsoon system at fine temporal resolution is receiving increased attention (Lister et al. 1991; Henderson 2004; Shen et al. 2005). Two sediment cores (QH85 and QH2000) have been recovered from the southern sub-basins (Kelts et al. 1989; Shen et al. 2005). Detailed analyses of mineralogy, stable isotope, pollen, and chemical elements on these cores revealed changes in the Asian monsoon during the last 18,000 yr (Lister et al. 1991; Shen et al. 2005). However, the precise timing of these changes using ${ }^{14} \mathrm{C}$ methods is subject to the uncertainty of the reservoir age of the lake. For example, extrapolating the ${ }^{14} \mathrm{C}$ age-depth models of cores QH84 (Figure 2C) and QH2000 (Figure 2D) reveals that the core tops have an apparent age of about 1200 yr. Ages in Core QH85 are from fossil seeds of Ruppia (Kelts et al. 1989), an underwater vascular plant using DIC for photosynthesis, whereas ages in QH2000 are from bulk OM (Shen et al. 2005). Assuming that the DIC and OM contributing to these samples come from various pre-aged sources, these apparent surface ages are presumably caused by the ${ }^{14} \mathrm{C}$ reservoir effect. ${ }^{14} \mathrm{C}$ dating of recent (post-bomb) DOC and DIC samples confirms the presence of dissolved pre-aged carbon in the lake water column (Henderson 2004). The DOC and DIC ${ }^{14} \mathrm{C}$ ages and the apparent surface ages obtained by extrapolation from depth, along with the hydrological data (Table 1), can provide a starting point for estimating the parameters that are poorly constrained in the box model constructed above. After optimization, we use this model to predict the pre-bomb reservoir age of the lake.

\section{Bayesian Approach to the Estimate of Model Parameters}

For most large lakes, including Lake Qinghai, observations of hydrological variables are usually available, but the magnitudes of carbon fluxes are poorly known. This knowledge gap prevents quantitative evaluation of the carbon budget, and a number of assumptions have to be made to estimate the reservoir age of the lake system. Here, we follow an inverse approach collectively known as the "data-model fusion" technique (Tarantola 2005). First, we use the Markov chain Monte Carlo (MCMC) method to infer the $\delta^{14} \mathrm{C}$ of DOC and DIC and their concentration in river and groundwater, using the post-bomb ${ }^{14} \mathrm{C}$ ages of DOC and DIC (Henderson 2004) together with the hydrological data (Table 1) in the box model. Assuming that these parameters remain constant over time, we then use this optimized model to predict the pre-bomb reservoir age of the DOC and the DIC pool.

Specifically, the MCMC technique is a probabilistic method that simulates the posterior expectation of model parameters, $\mathbf{m}$, by randomly sampling their joint posterior probability distribution $\pi(\mathbf{m} \mid \mathbf{d})$, which is usually given according to the Bayesian theorem:

$$
\pi(\mathbf{m} \mid \mathbf{d}) \propto L(\mathbf{d} \mid \mathbf{m}) \times P(\mathbf{m})
$$

where $L(\mathbf{d} \mid \mathbf{m})$ is the likelihood function, $P(\mathbf{m})$ the prior probability of model parameters, and $\mathbf{d}$ the data space. Equation 12 states that the prior information of the model parameters can be updated by the likelihood function. Here, we simply assume a uniform distribution for the prior probability. The likelihood function is defined as the Gaussian process between observation and modeled results:

$$
\begin{aligned}
& L(\mathbf{d} \mid \mathbf{m})=\prod_{i=1}^{N} L\left(d_{i} \mid u_{i}(\mathbf{m})\right) \\
& \propto \exp \left(-\sum_{i=1}^{N} \frac{\left(u_{i}(\mathbf{m})-d_{i}\right)^{2}}{2 \sigma^{2}}\right)
\end{aligned}
$$


Table 1 Parameters and their values used in the box model for the Lake Qinghai case.

\begin{tabular}{|c|c|c|c|c|}
\hline Parameters & Definition & Values & Units & Data sources \\
\hline$V_{\mathrm{RI}}$ & Annual river discharge & $1.5 \times 10^{9}$ & $\mathrm{~m}^{3} / \mathrm{yr}$ & Kelts et al. 1989 \\
\hline$V_{\mathrm{GI}}$ & Annual groundwater discharge & $0.6 \times 10^{9}$ & $\mathrm{~m}^{3} / \mathrm{yr}$ & Kelts et al. 1989 \\
\hline$V_{\mathrm{W}}$ & Lake volume & $86 \times 10^{9}$ & $\mathrm{~m}^{3}$ & Kelts et al. 1989 \\
\hline$F_{\mathrm{R} 0}$ & $\begin{array}{l}\text { Concentration of DIC in river } \\
\text { water }\end{array}$ & - & $\mathrm{mol} / \mathrm{m}^{3}$ & Estimated herein \\
\hline$F_{\mathrm{R} 1}$ & $\begin{array}{l}\text { Concentration of } \mathrm{DOC} \text { in river } \\
\text { water }\end{array}$ & - & $\mathrm{mol} / \mathrm{m}^{3}$ & Estimated herein \\
\hline$F_{\mathrm{G} 0}$ & $\begin{array}{l}\text { Concentration of DIC in } \\
\text { groundwater }\end{array}$ & - & $\mathrm{mol} / \mathrm{m}^{3}$ & Estimated herein \\
\hline$F_{\mathrm{G} 1}$ & $\begin{array}{l}\text { Concentration of DOC in } \\
\text { groundwater }\end{array}$ & 0 & $\mathrm{~mol} / \mathrm{m}^{3}$ & RCRE-CAS 1994 \\
\hline$F_{\mathrm{W} 0}$ & $\begin{array}{l}\text { Concentration of DIC in lake } \\
\text { water }\end{array}$ & 19.95 & $\mathrm{~mol} / \mathrm{m}^{3}$ & RCRE-CAS 1994 \\
\hline$F_{\mathrm{W} 1}$ & $\begin{array}{l}\text { Concentration of DOC in lake } \\
\text { water }\end{array}$ & - & $\mathrm{mol} / \mathrm{m}^{3}$ & Estimated herein \\
\hline$A_{0}$ & $\begin{array}{l}\text { Annual addition of atmo- } \\
\text { spheric } \mathrm{CO}_{2}\end{array}$ & $0.33 \times 10^{9}$ & $\mathrm{~mol} / \mathrm{yr}$ & Einsele et al. 2001 \\
\hline$A_{1}$ & $\begin{array}{l}\text { Annual photosynthetic uptake } \\
\text { of } \mathrm{CO}_{2}\end{array}$ & $2.5 \times 10^{9}$ & $\mathrm{~mol} / \mathrm{yr}$ & Einsele et al. 2001 \\
\hline$\delta_{\mathrm{A}}$ & $\begin{array}{l}{ }^{14} \mathrm{C} \text { activity of post-bomb } \\
\text { atmosphere }\end{array}$ & 120 & $\%$ modern & Pearson et al. 1986 \\
\hline$\delta_{\mathrm{RA}}$ & $\begin{array}{l}{ }^{14} \mathrm{C} \text { activity of reference atmo- } \\
\text { sphere }\end{array}$ & 100 & $\%$ modern & - \\
\hline$\delta_{\mathrm{R} 0}$ & $\begin{array}{l}{ }^{14} \mathrm{C} \text { activity of DIC in river } \\
\text { water }\end{array}$ & - & $\%$ modern & Estimated herein \\
\hline$\delta_{\mathrm{R} 1}$ & $\begin{array}{l}{ }^{14} \mathrm{C} \text { activity of DOC in river } \\
\text { water }\end{array}$ & - & $\%$ modern & Estimated herein \\
\hline$\delta_{\mathrm{G} 0}$ & $\begin{array}{l}{ }^{14} \mathrm{C} \text { activity of DIC in ground- } \\
\text { water }\end{array}$ & - & $\%$ modern & Estimated herein \\
\hline$\delta_{\mathrm{G} 1}$ & $\begin{array}{l}{ }^{14} \mathrm{C} \text { activity of DOC in ground- } \\
\text { water }\end{array}$ & Arbitrary & $\%$ modern & - \\
\hline$\lambda$ & ${ }^{14} \mathrm{C}$ decay constant & $1 / 8267$ & $\mathrm{yr}^{-1}$ & - \\
\hline$\kappa$ & OM decomposition constant & 0.001 & $\mathrm{yr}^{-1}$ & Westrich and Berner 1984 \\
\hline$\omega$ & Sedimentation rate & 1.4 & $\mathrm{~mm} / \mathrm{yr}$ & $\begin{array}{l}\text { Shen et al. 2001; } \\
\text { Henderson } 2004\end{array}$ \\
\hline$D$ & $\begin{array}{l}\text { Thickness of early diagenesis } \\
\text { zone }\end{array}$ & 70 & $\mathrm{~mm}$ & Xu et al. 2006a,b \\
\hline
\end{tabular}

Taken together, the posterior probability distribution of model parameters can be expressed as:

$$
\begin{gathered}
\pi(\mathbf{m} \mid \mathbf{d}) \propto L(\mathbf{d} \mid \mathbf{m}) \times P(\mathbf{m}) \\
\propto \prod_{i=1}^{N} L\left(d_{i} \mid u_{i}(\mathbf{m})\right) \\
\propto \exp \left(-\sum_{i=1}^{N} \frac{\left(u_{i}(\mathbf{m})-d_{i}\right)^{2}}{2 \sigma^{2}}\right)
\end{gathered}
$$

Given the fact that the posterior probability distribution, $\pi(\mathbf{m} \mid \mathbf{d})$, represents the sum of the knowledge available, the objective of inverse modeling is to seek the posterior expectation of the model 
parameters through a high-dimensional (Monte Carlo) integral. According to the Central Limit theorem, the posterior expectation can be approximated using the ergodic average of a Markov chain consisting of random draws from the posterior probability distribution. There are several methods that can be used to generate a Markov chain from a given posterior probability distribution. Here, we use the random walk Metropolis-Hastings algorithm (Gilks et al. 1996).

Given the ${ }^{14} \mathrm{C}$ ages $\mathbf{d} \subset\{10 \mathrm{yr}\}$ for the DIC pool, and $\mathbf{d} \subset\{661 \pm 32 \mathrm{yr}\}$ for the DOC pool (Henderson 2004), the parameters $\mathbf{m} \subset\left\{\delta^{14} \mathrm{C}_{\mathrm{R}}, \delta^{14} \mathrm{C}_{\mathrm{G}}, F_{\mathrm{R}}, F_{\mathrm{G}}\right\}$ for the former and $\mathbf{m} \subset\left\{\delta^{14} \mathrm{C}_{\mathrm{R}}, F_{\mathrm{R}}, F_{\mathrm{L}}\right\}$ for the latter were estimated using the MCMC method. The contribution of groundwater to the DOC pool was assumed to be negligible in this case. After about 1000 iterations, the chains begin to lose the "memory" of their starting values and tend to converge. The posterior distribution of these parameters and their mean with 1- $\sigma$ standard deviation are presented in Figure 3 for DIC and in Figure 4 for DOC. Our MCMC estimates indicate that the $\delta^{14} \mathrm{C}$ of DIC in recent river water is about $118 \%$ modern (i.e. AD 1950), implying an nearly equilibrium state of gas exchange between the river water and the atmosphere ( 120\% modern [Pearson et al. 1986]). However, the DIC in recent groundwater appears to be extremely old ( $\sim 76 \%$ modern), which is equivalent to $\sim 65 \%$ of the postbomb atmospheric $\delta^{14} \mathrm{C}$ level (Pearson et al. 1986). This value is very close to the theoretical calculations that will be discussed in the following section. Our estimates also indicate the presence of pre-aged DOC in the river water ( $70 \%$ modern), most likely reworked from the catchment topsoil.
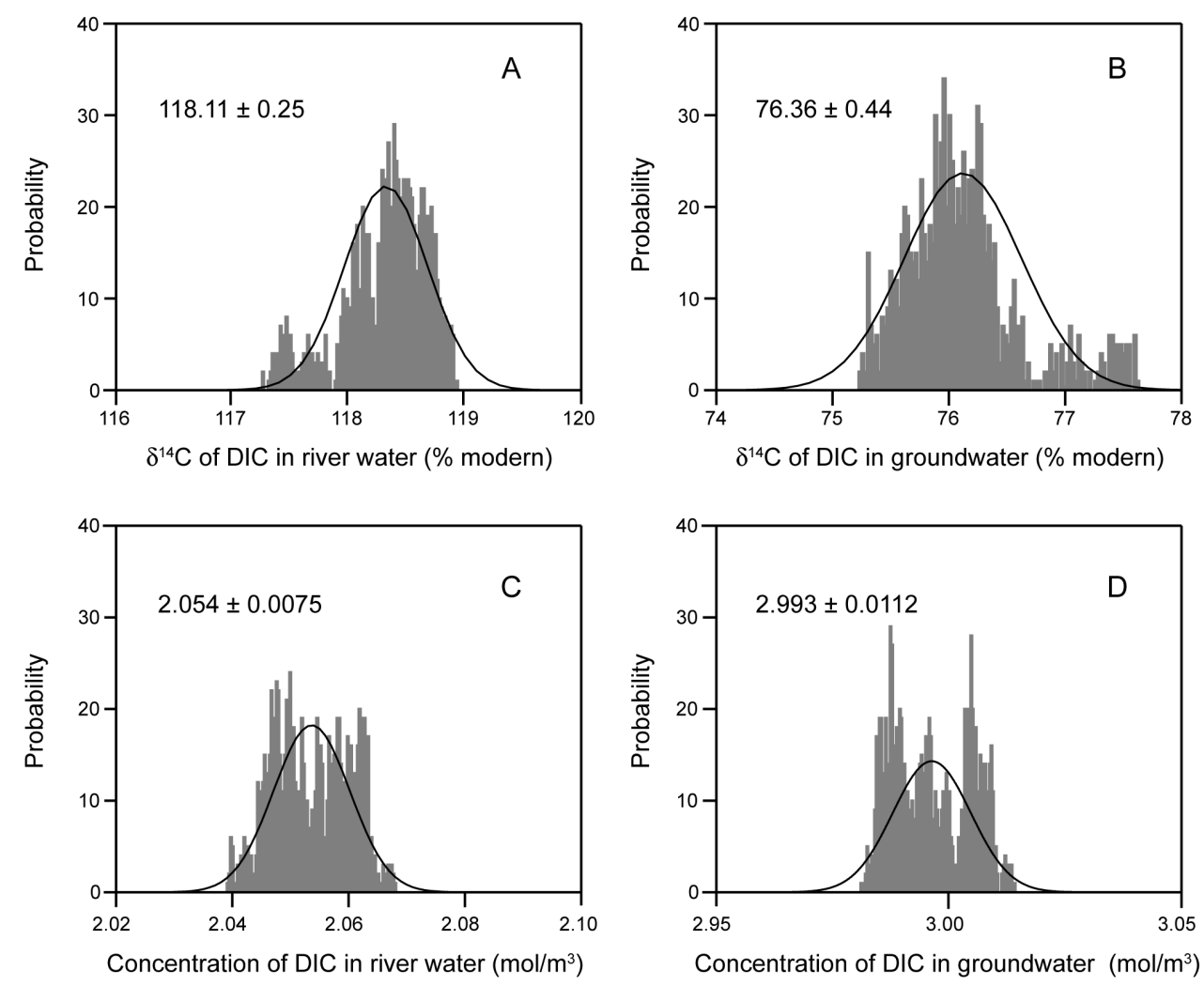

Figure 3 Markov chain Monte Carlo outputs of the posterior probability distribution of model parameters. Solid lines are the fits using a Gaussian probability distribution function. A) $\delta^{14} \mathrm{C}$ of DIC in river water; B) $\delta^{14} \mathrm{C}$ of DIC in groundwater; C) concentration of DIC in river water; and D) concentration of DIC in groundwater. 

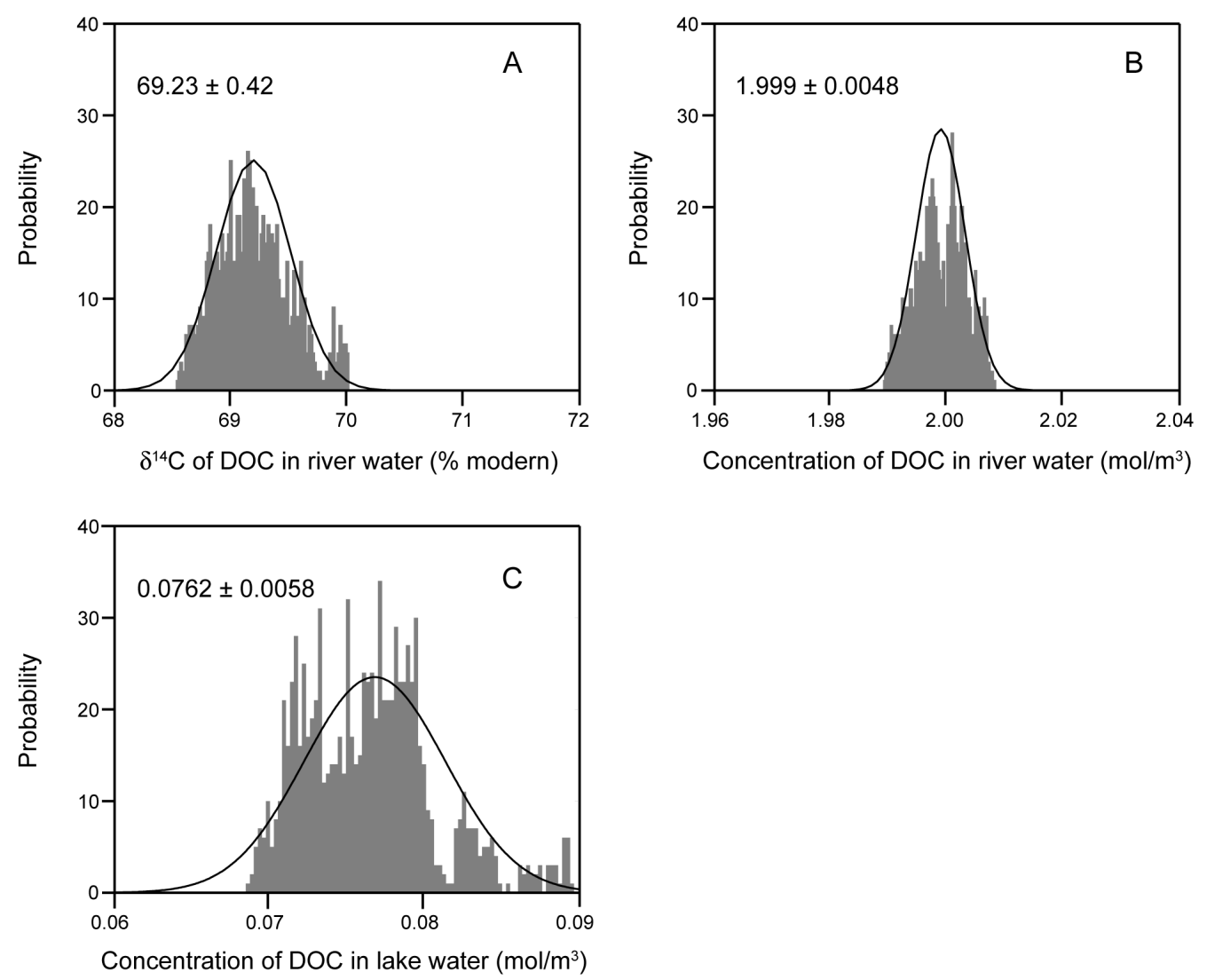

Figure 4 Markov chain Monte Carlo outputs of the posterior probability distribution of model parameters. Solid lines are the fits using a Gaussian probability distribution function. A) $\delta^{14} \mathrm{C}$ of DOC in river water; B) concentration of DOC in river water; and C) concentration of DOC in lake water.

\section{Pre-Bomb Reservoir Age of DIC}

${ }^{14} \mathrm{C}$ analysis of DIC in recent (2003) lake water yields an apparent age of about 5-10 yr (Henderson 2004). Therefore, to offset the addition of ${ }^{14} \mathrm{C}$-rich, post-bomb atmospheric $\mathrm{CO}_{2}$ into the lake water, our inverse modeling indicates that a contribution of old groundwater with a ${ }^{14} \mathrm{C}$ activity of $\sim 76 \%$ modern is required (Figure 3A). This estimate compares well with the value (80\% modern) for an impure carbonate watershed (Broecker and Walton 1959). Note that this value would be slightly lower during the pre-bomb era, perhaps $65 \%$ modern, because the atmospheric ${ }^{14} \mathrm{C}$ level at that time was different from the present-day value. Likewise, the ${ }^{14} \mathrm{C}$ activity of DIC in river water should be proportionally reduced to $98 \%$ modern for the pre-bomb era. Using the parameter estimates from the MCMC exercise, we then can estimate the pre-bomb reservoir age of the DIC pool by assuming constant hydrological conditions. Our model predicts a reservoir age of $1500 \pm 60 \mathrm{yr}$ for the pre-bomb DIC pool, very close to the apparent core-top age obtained by extrapolation from the age-depth model of Core QH-85 (Figure 2C). Importantly, if the ${ }^{14} \mathrm{C}$ activity of DIC in both river and groundwater is set to $100 \%$ modern during the pre-bomb era, a reservoir age of $\sim 320 \mathrm{yr}$ still exists, primarily caused by the radioactive decay of DIC while it circulates in the lake water column. The estimated DIC turnover rate is considerably longer than the average hydrological residence time of 33 yr (Lister et al. 1991). 


\section{Pre-Bomb Reservoir Age of DOC}

DOC in lakes is essentially derived from 2 sources: 1) decomposition of the photosynthetically fixed organic carbon in the epilimnion (i.e. autochthonous); and 2) riverine-derived humic substances (allochthonous). The autochthonous DOC should have an apparent age of zero. However, the terrestrial DOC, mainly derived from the decomposition of plant or animal tissues in the topsoil, might have been considerably pre-aged (Tonneijck et al. 2007), thereby imparting an apparent age to the lake water. For example, the present-day DOC pool has an apparent age of $661 \pm 32 \mathrm{yr}$ (Henderson 2004), evidently indicating the presence of pre-aged DOC from the catchment. Using the MCMC estimates of the model parameters, and assuming the same hydrological conditions as the post-bomb era, our model predicts a reservoir age of $1520 \pm 40 \mathrm{yr}$ for the pre-bomb DOC pool, generally consistent with the apparent core-top age extrapolated from the age-depth model of Core QH2000 (Figure 2D).

\section{Reservoir Age Due to Early Diagenesis}

According to Equation 11, the reservoir age resulting from early diagenesis processes is mainly a function of decomposition or the dissolution constant and sedimentation rate. The former determines the rate of decomposition of OM or dissolution of authigenic carbonate, and the latter controls the residence time of the carbon in the early diagenesis zone. The relative importance of these 2 parameters will be discussed later. For inorganic carbon, assuming a very slow dissolution rate, the reservoir age in the early diagenesis zone only depends on sedimentation rate. In Lake Qinghai, sedimentation rates for the last $200 \mathrm{yr}$ have been independently determined using ${ }^{210} \mathrm{~Pb}$ and ${ }^{137} \mathrm{Cs}$ methods (Huang and Sun 1989; Zhang 2003; Henderson 2004). Given an average sedimentation rate of $1.4 \mathrm{~mm} / \mathrm{yr}$ for the southern sub-basin (Shen et al. 2001; Henderson et al. 2003) and a thickness of $7 \mathrm{~cm}$ for the early diagenesis zone (Xu et al. 2006a,b), the reservoir age of authigenic carbonate due to early diagenesis was calculated to be $\sim 50 \mathrm{yr}$. Most of this "reservoir age" is simply the transit time of sediments from the sediment-water interface to the base of the early diagenesis zone. Similarly, given the relatively high sedimentation rate in this lake, the reservoir age of OM due to early diagenesis, independent of transit time in the early diagenesis zone, appears to be small (about $50 \mathrm{yr}$ ) even if an extremely low decomposition constant, say 0.001 (Westrich and Berner 1984), is applied (Figure 5).

\section{DISCUSSION}

\section{Catchment Weathering and the $\delta^{14} \mathrm{C}$ of DIC in Groundwater}

DIC in lake water is primarily derived from the addition of atmospheric $\mathrm{CO}_{2}$ and from the weathering of calcareous and/or siliceous rocks in the watershed or in an aquifer. The free $\mathrm{CO}_{2}$ in river and groundwater is assumed to be in isotopic equilibrium with the atmosphere, which is supported by our inverse modeling using DIC and DOC ages. Therefore, DIC derived from free $\mathrm{CO}_{2}$ does not appear to have much of an apparent age. In contrast, the DIC delivered to the lake in groundwater could be considerably pre-aged. This is true for the lakes on the western Tibetan Plateau (Fontes et al. 1993). The weathering of carbonate and silicate minerals can be expressed as (Broecker and Walton 1959):

$$
\begin{gathered}
\mathrm{Ca}^{14} \mathrm{CO}_{3}+\mathrm{H}_{2} \mathrm{O}+{ }^{14} \mathrm{CO}_{2} \Rightarrow \mathrm{Ca}^{2}+2 \mathrm{H}^{14} \mathrm{CO}_{3}^{-} \\
\mathrm{CaAl}_{2} \mathrm{Si}_{2} \mathrm{O}_{8}+\mathrm{H}_{2} \mathrm{O}+2{ }^{14} \mathrm{CO}_{2} \Rightarrow \mathrm{Ca}^{2}+2 \mathrm{H}^{14} \mathrm{CO}_{3}^{-}+\mathrm{Al}_{2} \mathrm{O}_{3}+2 \mathrm{SiO}_{2}
\end{gathered}
$$




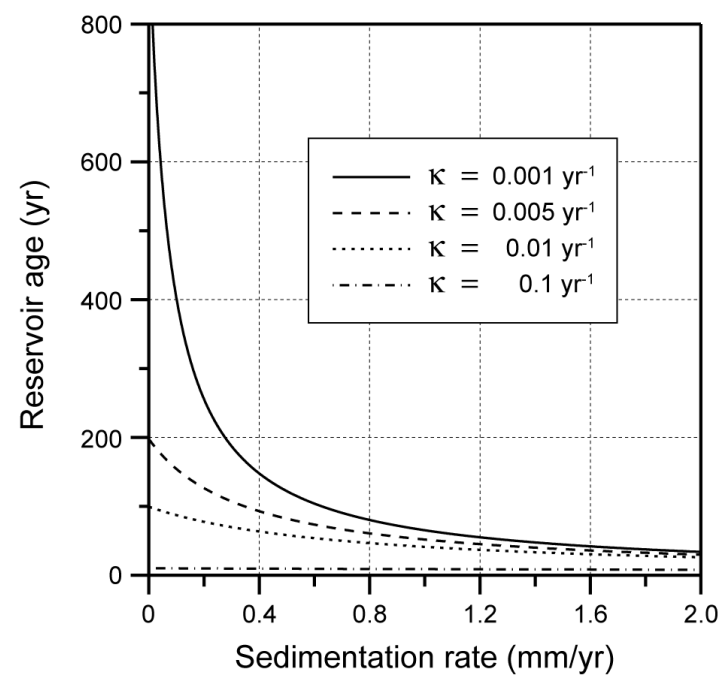

Figure $5{ }^{14} \mathrm{C}$ reservoir age due to early diagenesis of OM plotted against sedimentation rate for 4 different decomposition rates.

In the first reaction, $1 \mathrm{~mol}$ of atmospheric $\mathrm{CO}_{2}$ is required to dissolve the equivalent amount of carbonate, during which $2 \mathrm{~mol}$ of DIC are produced. Therefore, the ${ }^{14} \mathrm{C}$ of DIC from carbonate weathering, ${ }^{14} \mathrm{C}_{\mathrm{DICC}}$, is a mixture of the 2 sources with an equal proportion:

$$
\delta^{14} \mathrm{C}_{\mathrm{DICC}}=\frac{1}{2}\left(\delta^{14} \mathrm{C}_{\mathrm{C}}+\delta^{14} \mathrm{C}_{\mathrm{A}}\right)
$$

where ${ }^{14} \mathrm{C}_{\mathrm{A}}$ and ${ }^{14} \mathrm{C}_{\mathrm{C}}$ are the ${ }^{14} \mathrm{C}$ activity of atmospheric $\mathrm{CO}_{2}$ and carbonate, respectively. In the case of carbonate weathering, the mixture of old carbon from carbonate and atmospheric $\mathrm{CO}_{2}$ results in DIC with a minimum ${ }^{14} \mathrm{C}$ activity of $50 \%$ modern. However, in the second reaction, no ${ }^{14} \mathrm{C}$-poor carbon is added to the system, and the ${ }^{14} \mathrm{C}$ of DIC derived from silicate weathering, ${ }^{14} \mathrm{C}_{\mathrm{DICS}}$, is of atmospheric origin (i.e. ${ }^{14} \mathrm{C}_{\mathrm{DICS}}={ }^{14} \mathrm{C}_{\mathrm{A}}$ ). For a lake with a watershed composed of both rock types, such as Lake Qinghai, the ${ }^{14} \mathrm{C}$ of DIC in groundwater, ${ }^{14} \mathrm{C}_{\mathrm{G}}$, is accordingly a mixture of the 2 newly added components:

$$
\delta^{14} \mathrm{C}_{\mathrm{G}}=x \delta^{14} \mathrm{C}_{\mathrm{DICC}}+(1-x) \delta^{14} \mathrm{C}_{\mathrm{DICS}}=\left(1-\frac{x}{2}\right) \delta^{14} \mathrm{C}_{\mathrm{A}}+\frac{x}{2} \delta^{14} \mathrm{C}_{\mathrm{C}}
$$

where $x$ is the fraction of carbonate. For the case of Lake Qinghai, $x$ is $~ 80 \%$ (Einsele et al. 2001), and thus:

$$
\delta^{14} \mathrm{C}_{\mathrm{G}}=0.6 \times \delta^{14} \mathrm{C}_{\mathrm{A}}+0.4 \times \delta^{14} \mathrm{C}_{\mathrm{C}}
$$

Assuming the Paleozoic limestone is totally free of ${ }^{14} \mathrm{C}$ (i.e. ${ }^{14} \mathrm{C}_{\mathrm{C}}=0$ ), the minimum values of ${ }^{14} \mathrm{C}_{\mathrm{G}}$ should be $72 \%$ and $60 \%$ modern during the post- and pre-bomb era, respectively. However, our estimate of the post-bomb ${ }^{14} \mathrm{C}_{\mathrm{G}}$ is $\sim 76 \%$ modern, slightly above this lower limit. This difference most likely indicates the dissolution of carbonate with a non-zero ${ }^{14} \mathrm{C}$ age, for example, carbonate deposited relatively recently in the lake or watershed. 


\section{Effect of Early Diagenesis on the Reservoir Age of OM}

After being deposited on the sediment-water interface, OM experiences a number of biogeochemical alterations, such as aerobic decomposition, nitric reduction, sulfate reduction, and methanogenesis, collectively known as early diagenesis. These processes have been described in great detail as the " $G$ model" by Berner (1980). During these processes, the $\delta^{14} \mathrm{C}$ of OM may be further altered, for example, because of fractionation by sulfate-reducing or methanogenic bacteria (Raymond and Bauer 2001). In addition, OM ages because of radioactive decay of ${ }^{14} \mathrm{C}$ while the $\mathrm{OM}$ resides in the zone of early diagenesis. Therefore, the effect of early diagenesis on the reservoir age must be evaluated to properly interpret ${ }^{14} \mathrm{C}$ ages on $\mathrm{OM}$.

In our box model, we collectively dealt with these OM diagenesis processes as decomposition for the sake of simplification, and no $\delta^{14} \mathrm{C}$ fractionation was considered. According to Equation 11, the reservoir age of OM when it enters the early diagenesis zone depends on both the decomposition constant and the sedimentation rate. These 2 parameters determine the average residence time of $\mathrm{OM}$ in the early diagenesis zone. For example, in an anoxic environment the former is usually less than 0.001 (Westrich and Berner 1984), implying a slow turnover of OM in the early diagenesis zone, and thus the remaining OM would "age" so much, depending on the sedimentation rates and radioactive decay. Our modeling indicates that the apparent reservoir age due to early diagenesis could be erroneously large in anoxic environments, if the sedimentation rate is less than $0.2 \mathrm{~mm} / \mathrm{yr}$ (Figure 5). However, compared with marine settings, sedimentation rates in lacustrine settings are usually high $(>0.5 \mathrm{~mm} / \mathrm{yr}$ ), corresponding to a reservoir age of less than $100 \mathrm{yr}$ (Figure 5). Therefore, the reservoir age of $\mathrm{OM}$ due to early diagenesis in most lake sediment systems can be neglected.

\section{CONCLUSIONS}

A 2-component box model describing ${ }^{14} \mathrm{C}$ cycling in a lacustrine sediment system was formulated based on the principle of ${ }^{14} \mathrm{C}$ isotope mass balance. This model not only provides a mechanistic perspective on the ${ }^{14} \mathrm{C}$ reservoir effect in a lake sediment system, but also can be used to predict the ${ }^{14} \mathrm{C}$ reservoir age for a specific lake from preliminary DIC and DOC analyses if hydrological parameters are adequately known. The ${ }^{14} \mathrm{C}$ reservoir effect in a lake is primarily caused by the introduction of "old carbon" from various pre-aged sources to the lake from river and/or groundwater discharges. The flux of these ${ }^{14} \mathrm{C}$-deficient materials to the lake is a function of their concentration in the river and/or in the groundwater, as well as the hydrological properties of the lake, which in turn govern the extent to which the lake water column is out of equilibrium with atmospheric ${ }^{14} \mathrm{C}$. Our case study at Lake Qinghai, China, indicates that after discharge into the lake, DIC may be further aged while circulating in the lake water column, such that a minimum reservoir age of $320 \mathrm{yr}$ would have existed during the pre-bomb era. A 1500-yr reservoir age of both DIC and DOC during the prebomb era was predicted from the optimized box model. This value is generally consistent with the results obtained by extrapolating age-depth models of 2 sediment cores from depth to the sediment surface. Our modeling reveals that the reservoir age of OM due to early diagenesis could be significant, depending on both the oxic conditions and sedimentation rates, but that for lakes with a sedimentation rate higher than $0.5 \mathrm{~mm} / \mathrm{yr}$, this age can be neglected.

\section{ACKNOWLEDGMENTS}

We thank Richard D Ricketts and Brent J Dalzell for many stimulating discussions. We also thank Andrew C G Henderson for generously sharing his Lake Qinghai ${ }^{14} \mathrm{C}$ analyses with us, as well as for his helpful review of the manuscript. This work was partly supported by the National Science Foun- 
dation (EAR-0602412); Key Laboratory of Lake and Environment; Nanjing Institute of Geography and Limnology; Chinese Academy of Sciences; National Nature Science Foundation of China (Grant No. 40625007); and the Large Lakes Observatory, University of Minnesota, Duluth.

\section{REFERENCES}

Abbott MB, Stafford Jr TW. 1996. Radiocarbon geochemistry of modern and ancient Arctic lake systems, Baffin Island, Canada. Quaternary Research 45(3):300-11.

Benson L. 1993. Factors affecting ${ }^{14} \mathrm{C}$ ages of lacustrine carbonates: timing and duration of the last highstand lake in the Lahontan Basin. Quaternary Research 39(2):163-74.

Berner RA. 1980. Early Diagenesis: A Theoretical Approach. Princeton: Princeton University. $256 \mathrm{p}$.

Broecker WS, Olson EA. 1960. Radiocarbon from nuclear tests, II. Science 132(3429):712-21.

Broecker WS, Walton A. 1959. The geochemistry of ${ }^{14} \mathrm{C}$ in fresh-water systems. Geochimica et Cosmochimica Acta 16(1-3):15-38.

Cole JJ, Caraco NF, Kling GW, Kratz TK. 1994. Carbon dioxide supersaturation in the surface waters of lakes. Science 265(5178):1568-70.

Colman SM, King JW, Jones GA, Reynolds RL, Bothner MH. 2000. Holocene and recent sediment accumulation rates in southern Lake Michigan. Quaternary Science Reviews 19(16):1563-80.

Deevey ES, Stuiver M. 1964. Distribution of natural isotopes of carbon in Linsley Pond and other New England lakes. Limnology and Oceanography 9(1):1-11.

Deevey ES, Gross MS, Hutchinson GE, Kraybill HL. 1954. The natural ${ }^{14} \mathrm{C}$ contents of materials from hardwater lakes. Proceedings of the National Academy of Sciences (USA) 40(5):285-8.

Doran PT, Berger GW, Lyons WB, Wharton Jr RA, Davisson ML, Southon J, Dibb JE. 1999. Dating Quaternary lacustrine sediments in the McMurdo Dry Valleys, Antarctica. Palaeogeography, Palaeoclimatology, Palaeoecology 147(3-4):223-39.

Einsele G, Yan J, Hinderer M. 2001. Atmospheric carbon burial in modern lake basins and its significance for the global carbon budget. Global and Planetary Change 30(3-4):167-95.

Fontes JC, Mélières F, Gibert E, Qing L, Gasse F. 1993. Stable isotope and radiocarbon balances of two Tibetan lakes (Sumxi Co, Longmu Co) from 13,000 BP. Quaternary Science Reviews 12(10):875-87.

Fowler AJ, Gillespie R, Hedges REM. 1986. Radiocarbon dating of sediments. Radiocarbon 28(2A):44150

Geyh MA, Schotterer U, Grosjean M. 1998. Temporal changes of the ${ }^{14} \mathrm{C}$ reservoir effect in lakes. Radiocarbon 40(2):921-31.

Geyh MA, Grosjean M, Nuñez L, Schotterer U. 1999. Radiocarbon reservoir effect and the timing of the late-glacial/early Holocene humid phase in the Ata- cama Desert (northern Chile). Quaternary Research 52(2):143-53.

Gilks WR, Richardson S, Spiegelhalter DJ. 1996. Markov Chain Monte Carlo in Practice. Boca Raton: Chapman \& Hall/CRC. 512 p.

Godwin H. 1951. Comments on radiocarbon dating for samples from the British Isles. American Journal of Science 249:301-7.

Hall BL, Henderson GM. 2001. Use of uranium-thorium dating to determine past ${ }^{14} \mathrm{C}$ reservoir effects in lakes: examples from Antarctica. Earth and Planetary Science Letters 193(3-4):565-77.

Henderson ACG. 2004. Late Holocene environmental change on the NE Tibetan Plateau: a palaeolimnological study of Lake Qinghai and Lake Gahai, China, based on stable isotopes [unpublished $\mathrm{PhD}$ dissertation]. London: University College London.

Henderson ACG, Holmes JA, Zhang JW, Leng MJ, Carvalho LR. 2003. A carbon- and oxygen-isotope record of recent environmental change from Qinghai Lake, NE Tibetan Plateau. Chinese Science Bulletin 48: 1463-8.

Hendy CH, Hall BL. 2006. The radiocarbon reservoir effect in proglacial lakes: examples from Antarctica. Earth and Planetary Science Letters 241(3-4):41321.

Huang Q, Sun NJ. 1989. Preliminary study on depositing rate of Qinghai Lake and its evolution of paleoclimate. Chinese Science Bulletin 34:1457-62.

Kelts K, Chen KZ, Lister GS, Yu JQ, Gao ZH, Niessen N, Bonani G. 1989. Geological fingerprints of climate history: a cooperative study of Qinghai Lake, China. Eclogae Geologicae Helvetiae 82:167-82.

Lister GS, Kelts K, Chen KZ, Yu J-Q, Niessen F. 1991. Lake Qinghai, China: closed-basin lake levels and the oxygen isotope record for ostracoda since the latest Pleistocene. Palaeogeography, Palaeoclimatology, Palaeoecology 84(1-4):141-62.

MacDonald GM, Beukens RP, Kieser WE. 1991. Radiocarbon dating of limnic sediments: a comparative analysis and discussion. Ecology 72(3):1150-5.

Moreton SG, Rosqvist GC, Davies SJ, Bentley MJ. 2004. Radiocarbon reservoir ages from freshwater lakes, South Georgia, sub-Antarctic: modern analogues from particulate organic matter and surface sediments. $R a$ diocarbon 46(2):621-6.

Nelson RE, Carter LD, Robinson SW. 1988. Anomalous radiocarbon ages from Holocene detrital organic lens in Alaska and their implications for radiocarbon dating and paleoenvironmental reconstructions in the Arctic. Quaternary Research 29(1):66-71. 
Pearson GW, Pilcher JR, Baillie MGL, Corbett DM, Qua F. 1986. High-precision ${ }^{14} \mathrm{C}$ measurement of Irish oaks to show the natural ${ }^{14} \mathrm{C}$ variations from $\mathrm{AD} 1840$ to 5210 BC. Radiocarbon 28(2B):911-34.

Peng T-H, Broecker W. 1980. Gas exchange rates for three closed-basin lakes. Limnology and Oceanography 25(5):789-96.

Raymond PA, Bauer JE. 2001. Riverine export of aged terrestrial organic matter to the North Atlantic Ocean. Nature 409(6819):497-500.

RCRE-CAS (Research Center for Resource and Environment, Chinese Academy of Sciences). 1994. Evolution of Recent Environment in Qinghai Lake and Its Prediction. Beijing: Science Press. In Chinese.

Rea DK, Colman SM. 1995. Radiocarbon ages of prebomb clams and the hardwater effect in lakes Michigan and Huron. Journal of Paleolimnology 14(1):8991.

Shen J, Zhang EL, Xia WL. 2001. Records from lake sediments of the Qinghai Lake to mirror climatic and environmental changes of the past about 1000 years. Quaternary Sciences 21:508-13. In Chinese.

Shen J, Liu XQ, Wang SM, Matsumotob R. 2005. Palaeoclimatic changes in the Qinghai Lake area during the last 18,000 years. Quaternary International 136(1): $131-40$.

Stiller M, Kaufman A, Carmi I, Mintz G. 2001. Calibration of lacustrine sediment ages using the relationship between ${ }^{14} \mathrm{C}$ levels in lake waters and in the atmosphere: the case of Lake Kinneret. Radiocarbon
43(2B):821-30.

Stuiver M, Braziunas TF. 1993. Modeling atmospheric ${ }^{14} \mathrm{C}$ influences and ${ }^{14} \mathrm{C}$ ages of marine samples to 10,000 BC. Radiocarbon 35(1):137-89.

Tarantola A. 2005. Inverse Problem Theory and Methods for Model Parameter Estimation. Philadelphia: Society for Industrial and Applied Mathematics. 352 p.

Tonneijck FH, van der Plicht J, Jansen B, Verstraten JM, Hooghiemstra H. 2007. Radiocarbon dating of soil organic matter fractions in Andosols in northern Ecuador. Radiocarbon 48(3):337-53.

Westrich JT, Berner RA. 1984. The role of sedimentary organic matter in bacterial sulfate reduction: the $G$ model tested. Limnology and Oceanography 29(2): 236-49.

Xu H, Ai L, Tan L, An Z. 2006a. Geochronology of a surface core in the northern basin of Lake Qinghai: evidence from ${ }^{210} \mathrm{~Pb}$ and ${ }^{137} \mathrm{Cs}$ radionuclides. Chinese Journal of Geochemistry 25(4):301-6.

Xu H, Ai L, Tan L, An Z. 2006b. Stable isotopes in bulk carbonates and organic matter in recent sediments of Lake Qinghai and their climatic implications. Chemical Geology 235(3-4):262-75.

Xu S, Zheng G. 2003. Variations in radiocarbon ages of various organic fractions in core sediments from Erhai Lake, SW China. Geochemical Journal 37(1):135-44.

Zhang EL. 2003. Climate and environment change during the past 1000 years in Qinghai Lake [unpublished Master's thesis]. Graduate School of Chinese Academy of Sciences. 